Article

\title{
How Different Parental Leave Schemes Create Different Take-Up Patterns: Denmark in Nordic Comparison
}

\author{
Tine Rostgaard * and Anders Ejrnæs \\ Department of Social Sciences and Business, Roskilde University, 4000 Roskilde, Denmark; E-Mails: tiro@ruc.dk (T.R.), \\ ejrnaes@ruc.dk (A.E.) \\ * Corresponding author
}

Submitted: 24 November 2020 | Accepted: 15 March 2021 | Published: 11 June 2021

\begin{abstract}
The prevailing gender ideologies in the Nordic countries generally support the equal division of work and family life between men and women, including the equal sharing of parental leave. Regardless, as the exceptional case in the Nordic region, Denmark currently has no father's quota, and this despite the strong impact such policy has effectively proven to have on gender equality in take-up of parental leave. While a quota intended for the father is instead implemented in Denmark via collective agreements, this is mainly available for fathers in more secure labour market positions. This situates Danish fathers, mothers and their children very unequally regarding parental leave entitlements, and the existing inequalities continue across gender, social class and labour market positions. This article explores to what extent institutional variables vis-à-vis cultural explanations such as gender attitudes provide an understanding of why Danish fathers take less parental leave than other Nordic fathers. We use data from the European Values Study (1990-2017) as well as administrative data for fathers' parental leave take-up in the same period, relative to the other Nordics and for specific education backgrounds. We conclude that Danish men and women are even more supportive of gender equality in terms of work-family life sharing compared to other Nordic countries. This indicates that institutional conditions such as parental leave entitlement matter for leave take-up, but in the Danish case attitudes do less so. Not having a father's quota seems to affect fathers disproportionally across the education divide, and the lower parental leave take-up among Danish men with little education is primarily ascribed to their labour market insecurity. The policy implication is clear: If we want mothers and fathers with different social backgrounds to share parental leave more equally, the policy must change-not attitudes.
\end{abstract}

\section{Keywords}

Denmark; European Values Study; father's quota; gender equality; leave take-up; parental leave; statistics

\section{Issue}

This article is part of the issue "The Inclusiveness of Social Rights: The Case of Parental Leave Policies" edited by Sonja Blum (University of Hagen, Germany) and Ivana Dobrotić (University of Oxford, UK / University of Zagreb, Croatia).

(C) 2021 by the authors; licensee Cogitatio (Lisbon, Portugal). This article is licensed under a Creative Commons Attribution 4.0 International License (CC BY).

\section{Introduction}

Gender equality in work and family life is one of the pillars of the Nordic welfare model. There are long historical traditions of public policies supporting both parents with the care for new-born children, either as childcare or parental leave schemes (Eydal et al., 2015; Eydal \& Rostgaard, 2018). Parental leave policies divide the Nordic countries, however, particularly regarding the implementation of a father's quota: a separate, use-it-or- lose-it period of time after the maternity leave intended specifically for fathers to spend time with and care for their child on their own. In this way, the father's quota as policy instrument allows fathers to establish their own childcare practices and routines, which also makes it easier for them to claim their part of the parental leave, both in terms of claims toward their partner but also at the workplace, as this period would otherwise be lost for the family (Haas \& Rostgaard, 2011). The literature shows how these quota policies positively impact paternal leave 
take-up and contribute to a more gender-equal division of childcare with derived long-term effects on women's labour market participation, career opportunities and life earnings, as well as the division of informal care work between men and women (Duvander et al., 2019).

Unlike its Nordic neighbours, however, Denmark currently has no father's quota and the window of opportunity to introduce such policy appears to have shut (Rostgaard \& Lausten, 2014). Instead, the entitlement to a father's quota has increasingly been built into collective agreements and local work contracts. This situates fathers (and their partners and children) differently, as fathers in more vulnerable work positions and maledominated sectors tend not to have the entitlement. This article investigates the gendered consequences of not having a father's quota for parental leave take-up in general, and more specifically between fathers with different social class backgrounds-here, using education as a proxy. We investigate the importance of institutional variables such as parental leave entitlements relative to attitudes. In particular, we are interested whether attitudes to gender equality are reflected in the parental leave take-up, drawing here on data from the European Values Study (EVS). Acknowledging that there is no simple or one-way relationship between values, attitudes and behaviour (see Bergman, 1998), the article asks whether the low parental leave uptake among Danish fathers reflects a lack of attitudinal support for gender equality in childcare and paid work, both generally and according to social class.

Vis-à-vis its Nordic neighbours, the article presents Danish attitudes and parental leave policies before investigating the differences in parental leave take-up in Denmark according to gender and education background. The article shows how the low proportion of Danish fathers taking parental leave relative to other Nordic fathers is not due to any lack of generalized attitudinal support in Denmark for gender equality in work and family life, but rather due to the lack of gender-equal parental leave policies. We conclude by arguing that gender-equal parental leave take-up has never been viewed in Denmark as a real or urgent policy problem and has therefore not led to substantial policy change with consequences for families across gender and the social divide.

\section{Policies Matter; Or is it Rather Attitudes?}

Is behaviour determined by attitudes or policies? This is a classic conundrum in political science. Hakim (2000, 2004), as part of her preference theory, argued that various attitudinal factors, including work-lifestyle preferences, motivations and aspirations-are more important than institutional factors for understanding human behaviour and, more specifically so in her study, women's employment take-up. According to Hakim, modern welfare states offer sufficient choices that allow individuals to choose their individual pathways, and this despite the large structural differences across countries in, for example, their family policies. In contrast, authors with roots in historical institutionalism have argued that politics and policies matter. Esping-Andersen's (1990) seminal study on welfare regimes, for instance, has evaluated the institutional/structural impacts of various policy regimes on individual opinions on welfare policies (see also Arts \& Gelissen, 2001; Boje \& Ejrnæs, 2012; Esser, 2005; Korpi, 2000; Papadakis \& Bean, 1993; Sjöberg, 2004). More specifically regarding childcare and leave policies, Kangas and Rostgaard (2007) have shown that attitudes on family and working life certainly matter, and other studies (e.g., Duvander, 2014) have found genderequality orientation to matter for how fathers use parental leave. Highly educated men are argued to have more gender-equal attitudes and behaviour, not least regarding parental leave (Boll, Leppin, \& Reich, 2013; Geisler \& Kreyenfeld, 2011, 2019). However, genderequal attitudes may be constrained by opportunity structures for women and men that are typically not alike across different countries or education divides; opportunities also depend on institutional factors, such as childcare availability and gender-equality-focused leave policies. This leaves the question of whether attitudes or institutional factors-in this case, parental leave entitlements-drive the variation in leave take-up across gender and social class.

\section{Parental Leave and Childcare Policies in the Nordic Countries}

The Nordics stand out regarding institutional factors. There is strong institutional and political support for the Adult worker model (Lewis, 1992, 1993) aimed at ensuring that men and women can participate on equal footing in the labour market and in the division of care at home. In her seminal book, Hernes (1987) states that the family has gone public as welfare state has taken over care and proclaimed that the Nordic welfare states were strongly characterized by their 'women friendliness.'

\subsection{Childcare Policies in the Nordic Countries}

Accordingly, the Nordics invested early on in providing care for children outside the home. In Denmark in particular, the social contract between parents and state prescribes the provision of generous and affordable childcare of reasonable quality from an early age in return for women's high and full-time labour market participation (Boje \& Ejrnæs, 2013; Ejrnæs, 2011). Being cared for outside the family is regarded as being healthy and in the best interest of the child, and there is an individual right to childcare from the age of six months. Today, $57 \%$ of children up to two years of age and $89 \%$ of 3-year-olds are in public childcare (Bureau2000, 2018; figures from 2018). Characteristic of the Nordic countries is also that childcare is equally distributed. In most other OECD countries, children's participation in childcare differs with parental income and/or level of maternal 
education, and especially among children under the age of three. In the Nordic countries, children under three participate in childcare regardless of parents' income and education level, which is partly due to the relatively low out-of-pocket cost (Rostgaard, 2014, 2018a, 2018b).

\subsection{Nordic Leave Policy}

The Nordics also stand out in the early emphasis on gender equality in the leave provision, with Sweden being the first country to introduce parental leave in 1974, and it continues to distinguish itself, now with the longest total leave period among the Nordics, i.e., 69 weeks in total. As seen in Table 1, Denmark is somewhere in the middle. The total length of the Danish maternity, paternity and parental leave is 50 weeks total, which can be extended if taken part-time. While this is somewhat shorter than in Sweden, it is longer than in Finland, Iceland and Norway. As Table 1 illustrates, there is slight variation in the paternity leave length, with fathers being provided with between 2-3 weeks after the birth of their child. Iceland here is the exception, with no paternity leave. Leave is paid, compensation levels varying between $70-100 \%$ of former income, and the conditionality of parental-leave benefits is higher in Denmark than, for instance, in Norway (Dobrotić \& Blum, 2020). However, the real dividing line is the application of the policy tool of the father's quota. While Denmark does not apply this, other Nordic countries offer between 9-15 weeks.

The father's quota was introduced in the period between 1990 and the 2000s in Iceland, Norway and Sweden. In all three countries, the father's quota has proven to increase the percentage of father's taking parental leave considerably (Eydal \& Rostgaard, 2018; Eydal, Rostgaard, \& Hiilamo, 2018). Finland initially introduced gendered bonus, which became a father's quota in 2013, and Denmark also introduced a 2-week father's quota early on. It was in place from 1998-2002 and, in this period, the share of Danish fathers taking parental leave rose from 7 to $24 \%$ (Rostgaard \& Lausten, 2014). In 2002, the father's quota was replaced by a longer parental leave (32 weeks), giving parents a total of up to 52 weeks of maternity, paternity and parental leave. Despite its earlier intentions, the current SocialDemocratic government has not attempted to reinstall the father's quota, choosing instead to apply for an exemption from the EU Work-Life Balance Directive of 2019, regarding a 2-month quota. The Danish government proposed giving parents 16 weeks of parental leave each, but has since abandoned this policy, as it would violate the EU directive.

In this way, Denmark has departed from the other Nordics, not because of any critical juncture caused by an exogeneous chock, but rather as an incremental policy change (Thelen, 2004). It would also appear difficult to re-introduce a rhetorical frame that presents the lack of a father's quota as a policy problem, and the window of opportunity for (re-)introducing this as a policy instrument seems to have been lost somewhat (Beland \& Howlett, 2016; Kingdon, 1984).

\subsection{Father's Quota as a Labour Market Right: More for Some than Others}

Instead, the labour market partners representing employers and wage earners have been pushing for the re-introduction of a father's quota. In Denmark, parental leave is not only regulated via national legislation, but also via collective agreements between labour market partners (company-specific local agreements also exist). These labour market rights ensure full wage compensation during leave, but may be contingent on certain conditions, including the father using his father's quota and taking certain weeks of the parental leave period (or instead loses the right to full pay during leave). The vast majority of the workforce is covered by such collective agreements ( $100 \%$ in the public sector, $73 \%$ in the private sector; figures from 2018). The state does not guarantee these entitlements, however; they depend on being in employment and in a job covered by the collective agreement.

Interestingly, the private financial sector was actually the first to introduce a father's quota in the Danish context: In 2003, a 4-week father's quota with full pay was introduced. The father's quota has also been included in collective agreements in traditionally maledominated sectors, such as the industrial sector, where a paid 3-week father's quota with full pay was introduced in 2007 . This sector represents 18,000 private sector employers encompassing more than 300,000 employees (two-thirds of whom are men) nationwide, mainly within production (Statistics Denmark, n.d.-a). The number of weeks has been prolonged on multiple occasions

Table 1. Paid leave in Nordic countries (percentage of income and covered weeks; 2020 or most recent year).

\begin{tabular}{lccccc}
\hline & Iceland & Finland & Norway & Denmark & Sweden \\
\hline \% of income & 68 & 63 & 94 & 53 & 78 \\
Total leave weeks & 47 & 48 & 47 & 50 & 69 \\
$\quad$ Of which only father (father's quota) & 17 & 9 & 15 & 0 & 13 \\
Of which father with mother (paternity leave) & 0 & 3 & 2 & 2 \\
\hline
\end{tabular}

Note: Full-time leave. Source: Based on data from Duvander et al. (2019) and Moss and Duvander (2019). Benefit level data from $\operatorname{OECD}$ (n.d.). 
(five weeks at the time of our empirical investigation in 2017; at the renegotiation of the collective agreements in 2020, the father's quota was extended to eight weeks in the industrial sector). As regards the public sector, a 6-week father's quota was introduced in 2008, and an additional week was added in 2015. As of 2017, fathers employed in the public sector thus had the right to a 7-week father's quota, two more weeks than in the private, industrial sector.

This seems to position fathers differently across employment sectors, apparently benefitting fathers with higher education levels who are often already favoured by flexible working conditions. As this article investigates, the question becomes whether these institutional factors are mirrored in the actual take-up of parental leave or whether attitudinal factors are the main determinant.

\section{Methodology}

Our study combines high quality administrative data from Statistics Denmark and the Nordic Counsel with attitudinal survey data from the EVS, a large-scale, crossnational and longitudinal survey program that provides important insight into the attitudes, preferences and values in European countries. The survey data cover mainly 2017 (EVS, 2020), but one comparative analysis is supplemented with data from the 1990, 1999 and 2008 rounds. The administrative data is used to analyse the development in fathers' parental leave take-up in Denmark as well as the parental leave take-up levels among different education groups. To compare attitudes on gender roles in relation to work and care, we use EVS data.

The analysis applies EVS data from the whole sample to investigate general social norms rather than only including the attitudes of fathers (and mothers). Social norms refer to beliefs outside the individual that nevertheless function as a normative filter through which the individual father (and/or mother) may adjusts their values and actions (Ajzen, 1988). In this sense, social norms are "concerned with the likelihood that important referent individuals or groups approve or disapprove of performing a given behavior" (Ajzen, 1991, p. 195). Culturally dominant attitudes, for instance about masculinity and fatherhood, may even outweigh individualand household-level characteristics (Craig \& Mullan, 2010). In order to investigate whether there are particular gendered social norms, we analyse the responses for each gender in some of the analysis of attitudes.

In this article, we use three items from the EVS (2020) related to attitudes toward gender roles, family and work. These are:

1. "When a mother works for pay, the children suffer."

2. "A job is alright but what most women really want is a home and children."

3. "A man's job is to earn money; a woman's job is to look after the home and family."
For all three questions, the response categories are "strongly agree," "agree," "disagree" and "strongly disagree."

We recode the three variables into three binary variables by collapsing "strongly agree" with "agree" and "strongly disagree" with "disagree." The analysis of the EVS data consists of a time series analysis of the development in attitudes over time focusing on item 1, "when a mother works for pay, the children suffer," and a more detailed analysis of all three questions.

The total sample size in the five Nordic countries was 9,384 in 2017 (see the Supplementary File for national sample sizes). A considerable limitation in using EVS data is that one of the questions varies between countries and rounds: In 2017, in Finland, Norway and Sweden, but not in Denmark, the item "A pre-school child is likely to suffer if his or her mother works" was changed to a more general question: "When a mother works for pay, the children suffer." Regardless, the trend remains similar across the Nordic countries, which indicates that the change in the question has a limited impact on the Danish result.

To analyse the gendered consequences of attitudes regarding parental leave take-up, we use education as proxy for social class background in the analysis. Education is an important predictor of both values and attitudes that could influence parental leave take-up as well as the position in the labour market (Geisler \& Kreyenfeld, 2011).

\section{Gender Ideology in the Nordic Countries}

Overall, gender ideology refers to the attitudes regarding the appropriate roles, rights and responsibilities of men and women in society. In the article, we are initially interested in investigating whether there is an indication of a particular gender ideology in Denmark that may have driven the policy development differently than in the other Nordic countries; and, more specifically, drives a division in parental leave take-up between men and women and according to education in Denmark. Gender ideology may act as a lens through which individuals see their social world and upon which they make decisions, such as whether and when to set up family and human capital investments in education and employment. Over time, and with cohort replacement, individual characteristics contribute less and less to explaining whether an individual holds an egalitarian gender ideology, although women continue to be more likely to hold egalitarian gender ideologies than men (Davis \& Greenstein, 2009).

Likewise, support for gender equality may reflect the different institutional and cultural factors embedded in different policy and care regimes. In this way, there seems to be generally strong and increasing support for gender equality in the Nordic societies. This includes increasing support for equal sharing of paid and unpaid work in these societies, which is therefore at odds with the Danish policy development.

The central question for our analysis is whether the low parental leave take-up among Danish fathers reflects 
a lack of attitudinal support in Denmark for a more gender-equal division of childcare and paid work, generally as well as according to education divide as a proxy for social class.

\subsection{Changes over Time in Social Norms on Gender Roles in the Nordic Countries}

We first present the EVS data for the general population level and over time. Figure 1 shows that, for all of the Nordic countries, the percentage in the sample agreeing that "when a mother works for pay, the children suffer" has been declining (EVS, 2015, 2020). This reflects how the opposition toward work-oriented mothers is waning. Although the Nordics all follow the same trend, there are marked differences: Denmark has the lowest support for more traditional gender roles in all survey rounds, whereas we see the most rapid decline in the percentage agreeing that "when a mother works for pay, the children suffer" in Sweden. And the attitudes toward stay-at-home moms are converging in the Nordic countries, with a decline in the home-centric attitudes. Aside from Sweden and Finland, the curve flattens from 2008 to 2017.

\subsection{Social Norms on Gender Roles in the Nordic Countries}

Moving on to investigate the most recent round of the EVS study from 2017, we focus on three questions relating to gender roles (Table 2), now showing the responses according to gender. On the "When a mother works for pay, the children suffer" question, we find a gender difference in all countries. Overall, men are more like- ly to agree. Surprisingly, the gender difference is smallest among the Danish respondents (only 3 percentage points versus approx. 9 in Finland, Iceland and Sweden).

When it comes to gender-stereotypical attitudes toward the woman's role in the family, we also find some marked country and gender differences: Denmark has the lowest proportion of men and women agreeing that "a job is alright but what most women really want is a home and children." We find the highest proportion of respondents in Finland and Iceland agreeing that women want to stay at home; analysing how men and women respond to this question, we also find that Denmark has the lowest gender difference in gender stereotypical attitudes compared to the other Nordic countries. However, the proportion of gender-stereotypical attitudes is significantly higher among men than women throughout the Nordic region.

Finally, when it comes to the support for the malebreadwinner in a family, regarding the question "A man's job is to earn money; a woman's job is to look after the home and family," we find very little support in all of the countries, with the very least support in Denmark and the greatest support for a male-breadwinner model in Finland. Again, we also find that the support for a male-breadwinner family is significantly higher among men than women.

\subsection{Social Norms on Gender Roles in the Nordic Countries According to Education}

In the next figures, we investigate how education is associated with attitudes to gender and care. Figure 2 clearly shows that the proportion of respondents agreeing that

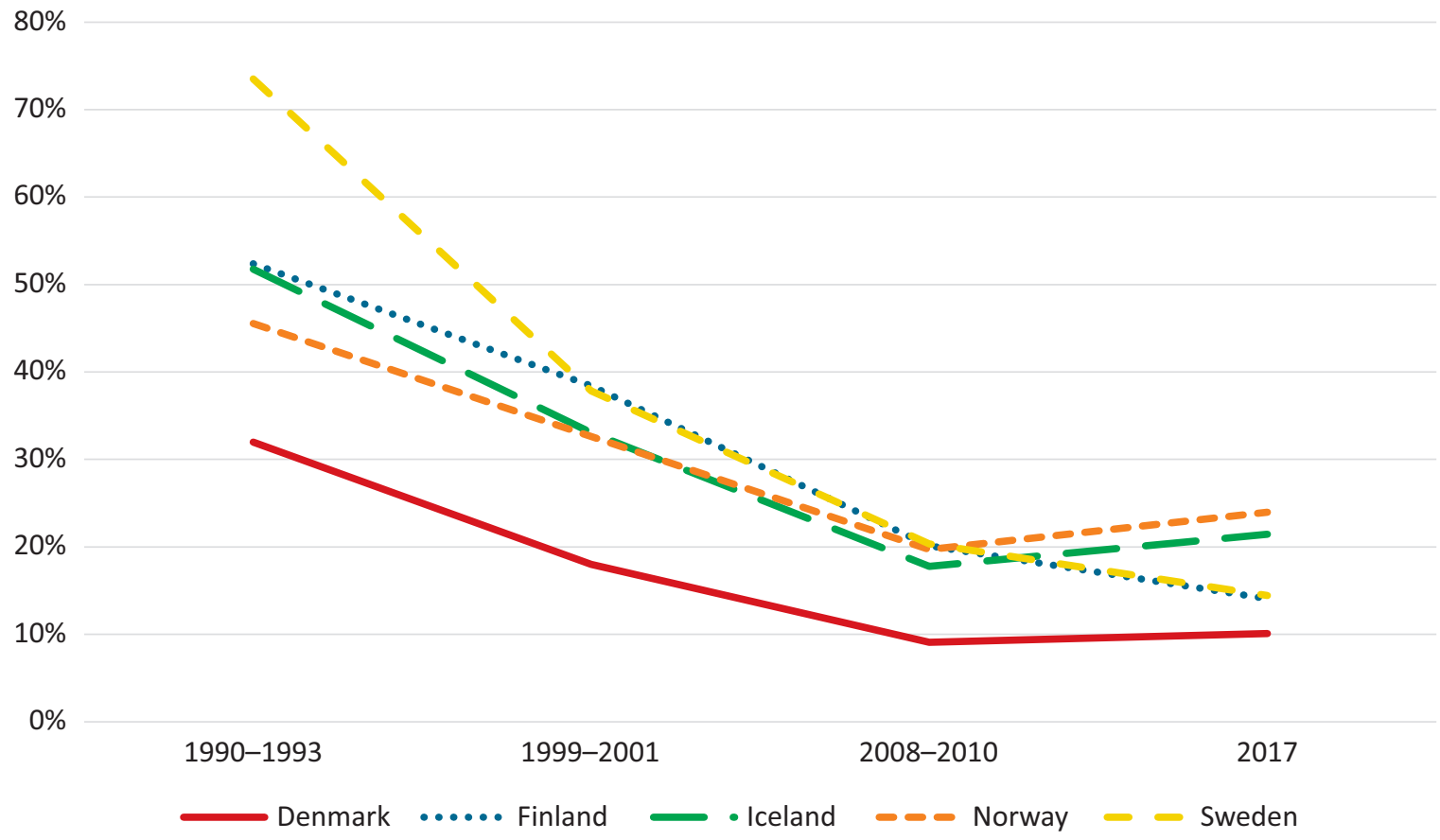

Figure 1. Percentage in sample agreeing that "when a mother works for pay, the children suffer" (all age groups, Nordic countries, 1990-2017). Note: ${ }^{* *} n=23,112$. Source: EVS $(2015,2020)$. 
Table 2. Attitudes toward gender and care, percentage agreeing to the three items among men and women (all age groups, Nordic countries, 2017).

\begin{tabular}{|c|c|c|c|c|c|c|c|c|c|c|c|c|c|c|c|}
\hline & \multicolumn{3}{|c|}{ Denmark } & \multicolumn{3}{|c|}{ Finland } & \multicolumn{3}{|c|}{ Iceland } & \multicolumn{3}{|c|}{ Norway } & \multicolumn{3}{|c|}{ Sweden } \\
\hline & $\frac{\Phi}{\tilde{N}}$ & $\begin{array}{l}\frac{0}{\sigma} \\
\stackrel{E}{U} \\
\amalg\end{array}$ & $\begin{array}{l}\frac{00}{n} \\
c\end{array}$ & $\frac{0}{\tilde{N}}$ & $\begin{array}{l}\frac{0}{\sigma} \\
\frac{E}{0} \\
\frac{1}{4}\end{array}$ & $\begin{array}{l}\frac{000}{n} \\
c\end{array}$ & $\frac{0}{\frac{0}{\sigma}}$ & $\begin{array}{l}\frac{0}{\sigma} \\
\frac{E}{0} \\
\frac{1}{\Psi}\end{array}$ & $\begin{array}{l}\frac{00}{n} \\
=\end{array}$ & $\frac{0}{\tilde{N}}$ & $\begin{array}{l}\frac{0}{\widetilde{D}} \\
\frac{\varepsilon}{U} \\
\sqcup\end{array}$ & $\begin{array}{l}\frac{00}{n} \\
c\end{array}$ & $\frac{0}{\pi}$ & $\begin{array}{l}\frac{0}{\sigma} \\
\frac{E}{U} \\
\amalg\end{array}$ & $\begin{array}{l}\frac{000}{n} \\
c\end{array}$ \\
\hline $\begin{array}{l}\text { When a mother } \\
\text { works for pay, } \\
\text { the children } \\
\text { suffer }\end{array}$ & 12 & 9 & $3,298 * *$ & 19 & 10 & $1,170 * * *$ & 26 & 17 & $2,004 * * *$ & 26 & 22 & 1,119 & 19 & 10 & $1,175 * * *$ \\
\hline $\begin{array}{l}\text { A job is alright } \\
\text { but what most } \\
\text { women really } \\
\text { want is a home } \\
\text { and children }\end{array}$ & 13 & 11 & $3,293 *$ & 38 & 27 & $1,146 * * *$ & 46 & 37 & $1,996 * * *$ & 26 & 20 & $1,106 *$ & 24 & 13 & $1,160 * * *$ \\
\hline $\begin{array}{l}\text { A man's job is to } \\
\text { earn money; a } \\
\text { woman's job is } \\
\text { to look after the } \\
\text { home and family }\end{array}$ & 7 & 5 & $3,331 *$ & 14 & 10 & $1,176 *$ & 9 & 5 & $2,023 * * *$ & 12 & 6 & $1,123 * * *$ & 7 & 4 & $1,184 *$ \\
\hline
\end{tabular}

Notes: ${ }^{*} \mathrm{p}<0.05,{ }^{* *} \mathrm{p}<0.01,{ }^{* * *} \mathrm{p}<0.001$

a child suffers with a working mother is significantly lower among those with the longest educations in all countries. A traditional care ideal is much more widespread among those with less education. The strong relationship between education level and attitude could explain a higher take-up of parental leave among well-educated parents. However, the figure also indicates that the association between education and gender attitudes differs. This correlation appears lowest in Denmark and Iceland.
We have also run some additional analysis only with men and women with children under 14 years of age living in the household; the results do not differ substantially from the analysis using the whole sample.

If we look at the gender-stereotype attitude that women really want to stay home, we find the same picture (Figure 3): Those with less education view gender roles more traditionally. Again, we see that education has less influence on gender attitudes in Denmark; only

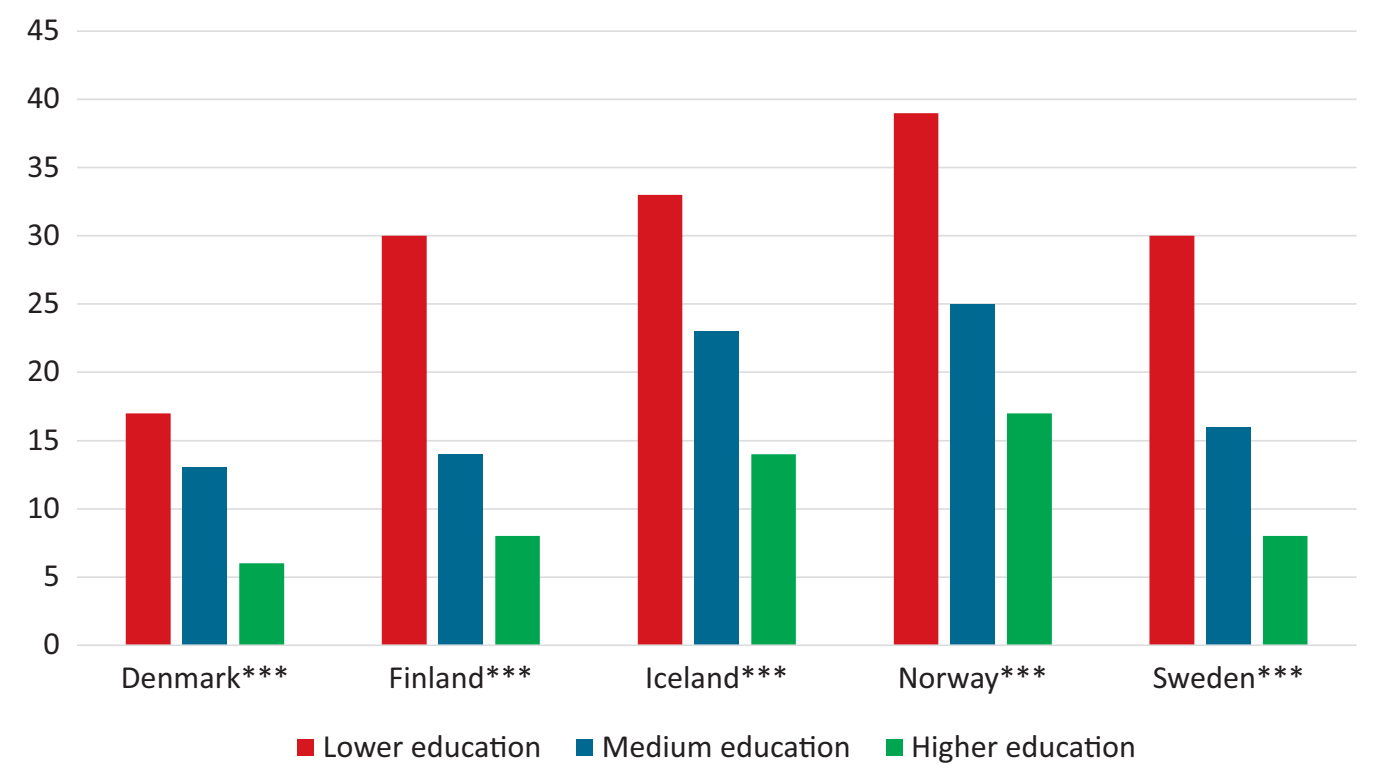

Figure 2. Percentage among different education groups agreeing that "when a mother works for pay, the children suffer" (all age groups, Nordic countries, 2017). Notes: ${ }^{*} \mathrm{p}<0.05,{ }^{* *} \mathrm{p}<0.01,{ }^{* * *} \mathrm{p}<0.001$; Denmark: $\mathrm{n}=3,233$, gamma $=-0.38$; Finland: $n=1,164$, gamma $=-0.45$; Iceland: $n=1,997$, gamma $=-0.35$; Norway: $n=1,098$, gamma $=-0.34$; Sweden: $\mathrm{n}=1,164$, gamma $=-0.43$. 


\section{COGITATIO}

70

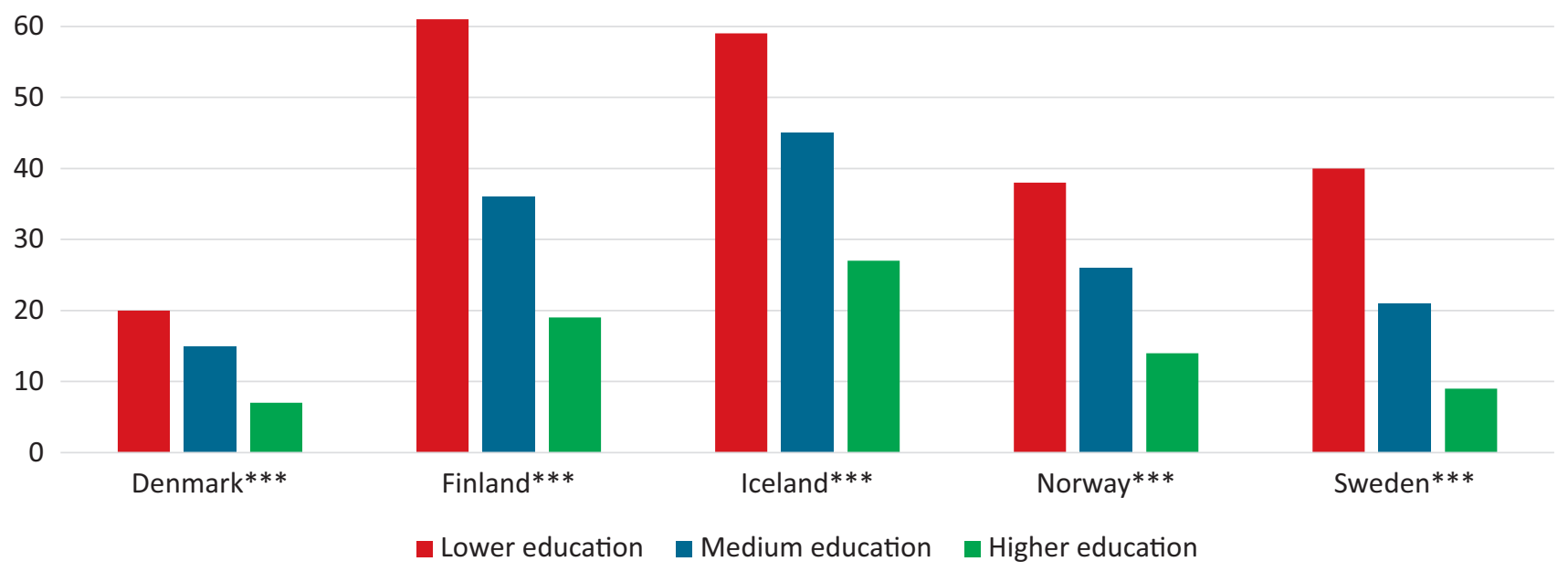

Figure 3. Percentage among different education groups agreeing that "a job is alright but what most women really want is a home and children" (all age groups, Nordic countries, 2017). Notes: ${ }^{*} p<0.05,{ }^{* *} p<0.01,{ }^{* * *} p<0.001$; Denmark: $\mathrm{n}=3,227$, gamma $=-0.38$; Finland: $\mathrm{n}=1,140$, gamma $=-0.51$; Iceland: $\mathrm{n}=1,986$, gamma $=-0.42 ;$ Norway: $n=1,086$, gamma $=-0.41 ;$ Sweden: $\mathrm{n}=1,150$, gamma $=-0.51$.

$20 \%$ of the least educated respondents agree that "job alright, but women really want home and children," compared to $58-60 \%$ in Finland and Iceland.

When it comes to attitudes in favour of a malebreadwinner family, there is a higher proportion of the least educated respondents agreeing that the man's responsibility is to earn money while the woman's responsibility is to look after home and family (Figure 4). However, in Denmark and Iceland the proportion is much lower. Again, the figure indicates that traditional genderrole attitudes are relatively uncommon in Denmark, even among the least educated.
A one-to-one causal relationship between attitudes and parental leave take-up is unlikely, as other structural and individual factors are involved (see, e.g., Lewis \& Haas, 2005). Failing to include questions regarding the paternal role in childcare also seriously limits the EVS survey. As Grunow, Begall, and Buchler (2018) show, multiple gender ideologies may coexist, and support for working mothers does not necessarily indicate similar support for caring fathers; lack of the latter could be a cultural explanation for fathers not taking leave, even in Denmark.

However, the analysis indicates that parental leave take-up among Danish men is not necessarily associated

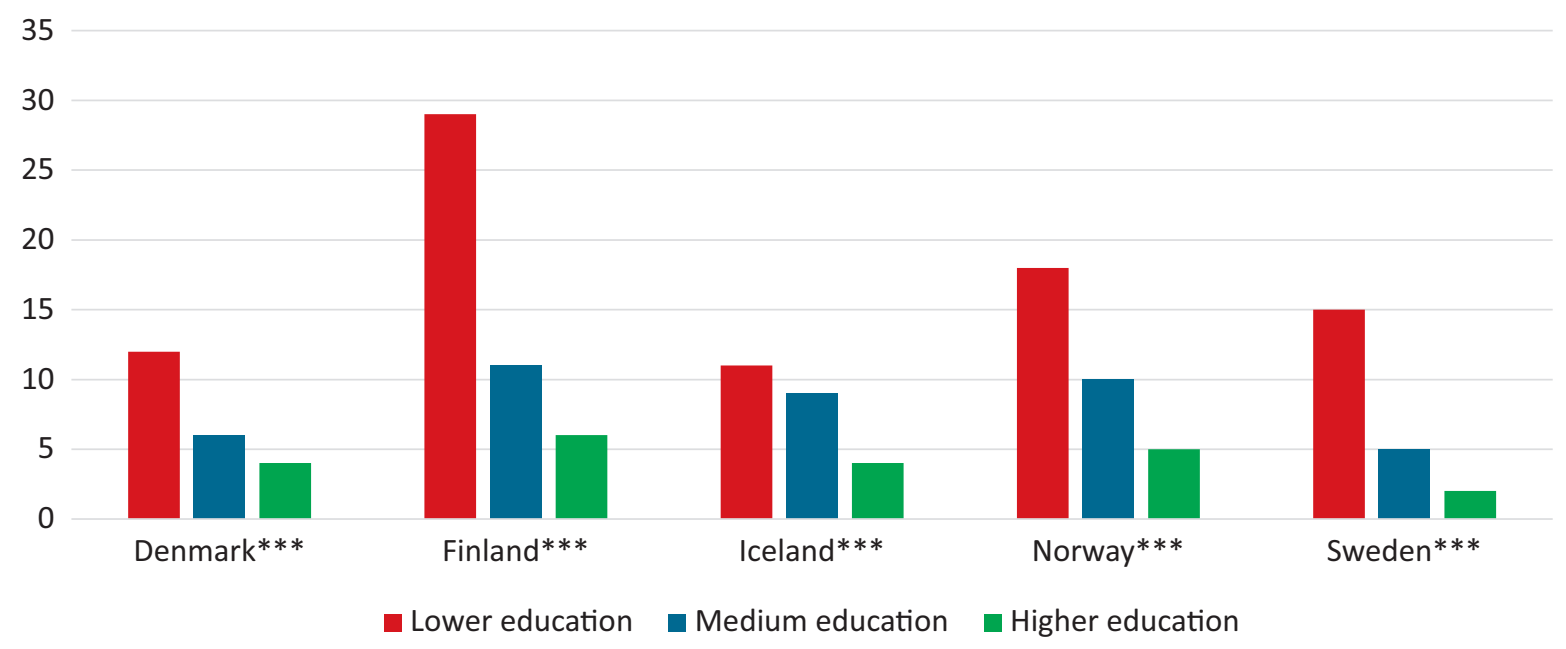

Figure 4. Percentage among different education groups agreeing that "a man's job is to earn money; a woman's job is to look after the home and family." Notes: ${ }^{*} p<0.05,{ }^{* *} p<0.01,{ }^{* * *} p<0.001$; Denmark: $\mathrm{n}=3,261$, gamma $=-0.37$; Finland: $n=1,169$, gamma $=-0.49$; Iceland: $n=2,016$, gamma $=-0.36$; Norway: $n=1,102$, gamma $=-0.42 ;$ Sweden: $n=1,174$, gamma $=-0.56$. 
with more traditional attitudes toward the gendered division of care work. Denmark has both the lowest gender difference in attitudes toward gender role and the lowest education gaps in attitude. It is also remarkable that when looking specifically at the group with the least education, the support for traditional care ideals is lowest in Denmark.

\section{Parental Leave Take-up: The Gender and Education Gradient}

As we have seen, the Danish social norms heavily favour gender equality, and the smallest education gap is also found here. The question is if this is mirrored in parental leave take-up across gender and education levels. Do we find a higher proportion of fathers taking parental leave in Denmark in comparison to the other Nordic countries, and regardless of educational background?

If we first look across the Nordic countries, it is remarkable how the changes in parental leave policies seem to have affected fathers' parental leave take-up. As of 2017, Icelandic fathers take the highest proportion of parental leave (30\%), Danish and Finnish fathers the lowest (both 11\%).

Reflecting that Iceland in some cases seems to have the most gender-traditional attitudes and Denmark the least, this suggests that parental leave policies with gender-equality incentives are effective policy instruments, rather than it being attitudes that drive gendered practices in leave take-up. The increase in fathers' share of total leave after 2000 in Sweden, Norway and Iceland seems to reflect the introduction of a fathers' quota in the period between 1990-2000.
Considering Denmark more specifically, the two weeks of earmarked parental leave introduced in 1998 did have an immediate effect on fathers' take-up of leave subsequent years. The highest recorded percentage of fathers taking parental leave was $36 \%$ in 2002 , a dramatic increase from the $12 \%$ in 1997 . But abolishing the father's quota in 2002 resulted in only $22 \%$ of fathers taking parental leave the following year. Figure 5 also indicates a slight increase from 2007 onwards in the percentage of fathers taking leave, suggesting a combined effect of the introduction of the labour market quotas and an overall shift in gender culture (Rostgaard \& Lausten, 2014).

More recently (due to a change in registration methods, only data from 2015 and onwards is comparable), we can see that Danish fathers have increased the average number of parental leave days taken over time, but only very gradually, from 29.3 days in 2015 to 31.9 in 2018 (only fathers entitled to a leave benefit, as this is considered the most correct way to account for leave take-up), which still leaves a long way to the two months proposed by the EU directive. In the same period, mothers' average number of days has decreased slightly from 275.5 days to 273.9 days (Figure 6). Since introducing parental leave in Denmark in 1984, mothers have traditionally taken the vast majority of parental leave days, and little seems to have changed. Therefore, the gendered division of parental leave seems to be constant in Denmark, with the likely risk of maintaining gendered inequalities in the division of paid and unpaid work, lifecourse income and the gender wage gap.

But does this development also maintain the divisions across the education divide? In fact, there was no

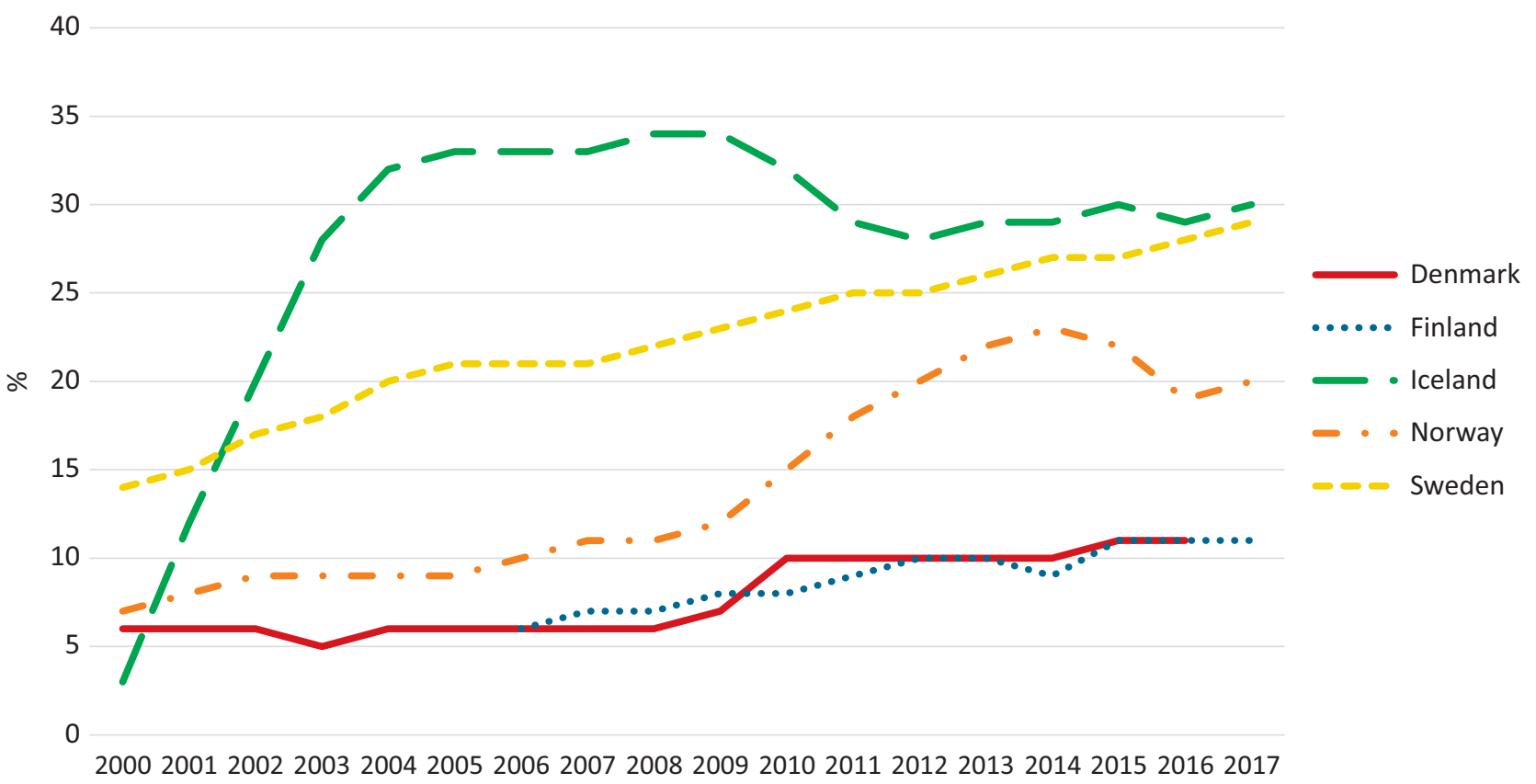

Figure 5. Fathers' parental leave take-up (share of total parental leave days; Nordic countries, 2000-2017). Source: NOSOSCO (n.d.) 


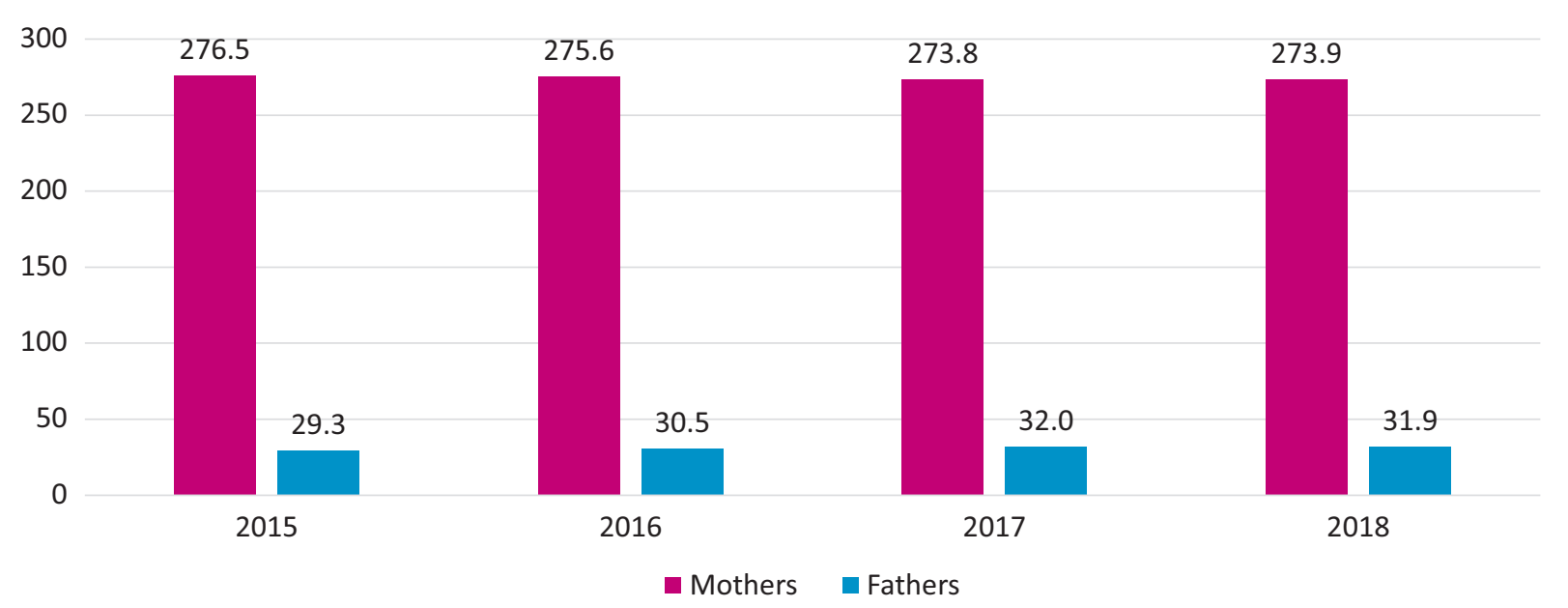

Figure 6. Number of parental leave days (average, fathers and mothers; Denmark, 2015-2018). Note: Cohabiting parents entitled to benefit. Source: Statistics Denmark (n.d.-b).

such division when parental leave was first introduced in Denmark in 1984. In the late 1980s, Christoffersen (1990) found that education level did not influence fathers' parental leave uptake. This has since changed, as indicated in Figure 7, which shows the average parental leave according to father's (and mother's) education for cohabiting couples. Education background now appears highly influential, fathers with the longest educations now taking the most leave days, and the least-educated fathers taking the fewest: Those with only lower-secondary schooling take on average approximately 26 days leave, compared to 56 days in couples where fathers have a master's degree. Other studies of parental leave among fathers document the same pattern (e.g., Duvander, 2014; Duvander \& Viklund, 2019). The figure also shows a combined effect of mother's education and father's leave take-up; male partners of highly educated women take longer leave, perhaps because the mother in this case prefers to share the leave and return to work sooner.
The continuing importance of educational homogamy (i.e., men and women mainly find a partner from within their own social class; Brannen \& Nilsen, 2006) situates fathers, mothers and their children in very unequal positions, where education background seems to be the influential factor. Parental leave take-up being closely associated with education levels is often seen as a matter of different gender values. In fact, parents' education is often used to indirectly measure norms and attitudes toward gender equality, with higher education likely being associated with more gender-equal norms, which drives leave take-up (Duvander \& Viklund, 2019). As shown in the section on gender attitudes, however, there is no such apparent association between education and gender equality attitudes in Denmark. This indicates that the development toward variation in fathers' parental leave take-up according to education is an expression of a social inequality, with some fathers in Denmark having less opportunity to take leave. This

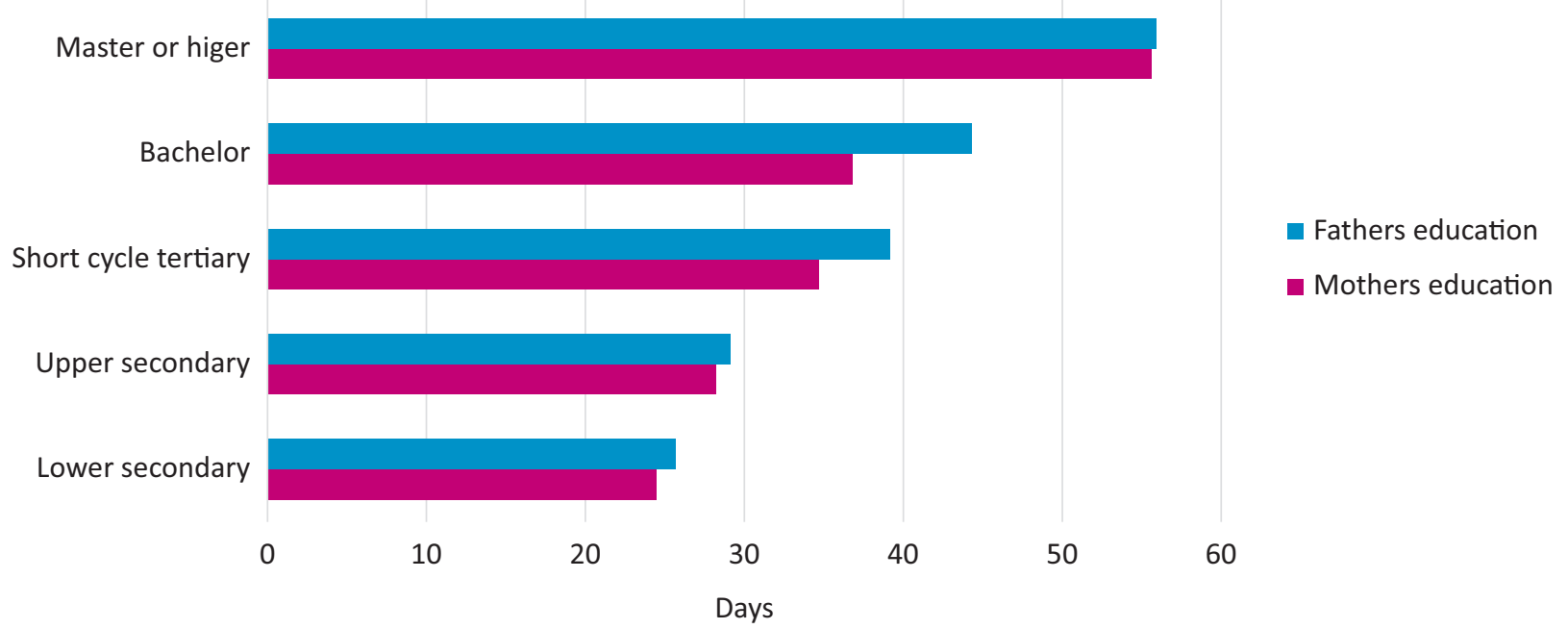

Figure 7. Fathers parental leave take-up (days) by education level (Denmark, 2018). Notes: Cohabiting couples only; both mother and father have taken parental leave. Source: Statistic Denmark (n.d.-c). 
might indicate that the low parental leave take-up among the least educated fathers not only reflects a traditional gender role attitude but also a lack of institutional support, such as gender-equality-focused leave policies.

\section{Conclusion}

The Nordic countries pioneered gender incentives in leave schemes, including the introduction of parental leave, but first and foremost the father's quota. This leaves Denmark as the regional outlier, as there is no longer a statutory father's quota; instead, labour market partners have introduced the father's quota in some collective agreements, and the right to this quota is accordingly secured only for those in more stable employment. While Denmark has invested massively in childcare outside the home, gender (in)equality in parental leave takeup is not part of the policy agenda to a degree that makes the current Social Democratic government consider a re-introduction of the father's quota; rather, along with other parties across the political spectrum, it has been opposed to the EU directive for a 2-month parental leave quota. Gender inequality in parental leave take-up therefore does not seem to be perceived as a problem requiring public action and is not part of the current policy stream.

The lack of political attention is regardless of how there is consistent gender inequality in leave take-up, and more so than in the other Nordic countries. Our analysis has found inequalities across the education divide, suggesting that social class also mitigates leave take-up. This education divide is not consistent with attitudes toward how mothers and fathers should share paid and unpaid work. In fact, Denmark seems to be the country most favoring gender equality in the region. We acknowledge that the survey data only addresses the role of the mother regarding gender roles and therefore does not show the norms related to the father's role in raising children. We are also aware that the items in the EVS represent rather extreme statements when it comes to examining gender roles in a Nordic context. This could explain the relative low level of agreement. Future comparative studies of how gender attitudes impact fathers' parental leave take-up should include survey questions about father as caregiver as well more nuanced questions about mother's and father's role as caregiver, which could better grasp the differences in gender attitudes between the Nordic countries. Regardless, the differences in leave take-up across gender and the education divide seem to reflect institutional and organizational barriers more than variation in the cultural perception of who should take parental leave. Ultimately, Danish fathers (and their children and their partners) are situated differently across the education divide regarding their rights to parental leave and how this is used, and mothers continue to take most of the leave. The policy implication is clear: If the desire is for mothers and fathers with different social backgrounds to share parental leave more equally, it is not the attitudes that must change, but rather the policy.

\section{Conflict of Interests}

The authors declare no conflict of interests.

\section{Supplementary Material}

Supplementary material for this article is available online in the format provided by the author (unedited).

\section{References}

Ajzen, I. (1988). Attitudes, personality and behavior. Milton Keynes: Open University Press.

Ajzen, I. (1991). The theory of planned behavior. Organizational Behavior and Human Decision Processes, 50(2), 179-211.

Arts, W., \& Gelissen, J. (2001). Welfare states, solidarity and justice principles: Does the type really matter? Acta Sociologica, 44(4), 283-299.

Beland, D., \& Howlett, M. (2016). The role and impact of the multiple-streams approach in comparative policy analysis: Introduction. Journal of Comparative Policy Analysis: Research and Practice, 18(3), 221-227.

Bergman, M. M. (1998). A theoretical note on the differences between attitudes, opinions and values. Swiss Political Science Review, 4(2), 81-93.

Boje, T. P., \& Ejrnæs, A. (2012). Policy and practice: The relationship between family policy regime and women's labour market participation in Europe. International Journal of Sociology and Social Policy, 32(9/10), 589-605.

Boje, T. P., \& Ejrnæs, A. (2013). Uligevægt: Arbejde og familie $i$ Europa [Imbalance: Work and families in Europe]. København: Nyt fra Samfundsvidenskaberne.

Boll, C., Leppin, J., \& Reich, N. (2013). Paternal childcare and parental leave policies: Evidence from industrialized countries. Review of Economics of the Household, 12(1), 129-158.

Brannen, J., \& Nilsen, A. (2006). From fatherhood to fathering: Transmission and change among British fathers in four-generation families. Sociology, 40(2), 335-352.

Bureau2000. (2018). Flere børn i dagtilbudUdviklingstendenser for dagpleje og daginstitutioner [More children in daycare-Development tendencies in childcare facilities]. Bureau2000. Retrieved from http://www.bureau2000.dk/seneste-nyt/170flere-born-i-dagtilbud-udviklingstendenser-fordagpleje-og-daginstitutioner-2018

Christoffersen, M. N. (1990). Barselsorlov-Mænds og kvinders erhvervsmæssige baggrund for at tage orlov [Parental leave-The professional backgrounds of men and women taking leave]. Copenhagen: Institute of Social Research. 
Craig, L., \& Mullan, K. (2010). Parenthood, gender and work-family time in the United States, Australia, Italy, France, and Denmark. Journal of Marriage and Family, 72(5), 1344-1361.

Davis, S. N., \& Greenstein, T. N. (2009). Gender ideology: Components, predictors, and consequences. Annual Review of Sociology, 35, 87-105.

Dobrotić, I., \& Blum, S. (2020). Inclusiveness of parentalleave benefits in twenty-one European countries: Measuring social and gender inequalities in leave eligibility. Social Politics: International Studies in Gender, State \& Society, 27(3), 588-614.

Duvander, A.-Z. (2014). How long should parental leave be? Attitudes to gender equality, family, and work as determinants of women's and men's parental leave in Sweden. Journal of Family Issues, 35(7), 909-926.

Duvander, A.-Z., \& Viklund, I. (2019). How long is a parental leave and for whom? An analysis of methodological and policy dimensions of leave length and division in Sweden. International Journal of Sociology and Social Policy, 40(5/6), 479-494.

Duvander, A.-Z., Eydal, G. B., Brandth, B., Gíslason, I. V., Lammi-Taskula, J., \& Rostgaard, T. (2019). Does parental leave lead to gender equality? Experiences from the Nordic countries. In P. Moss, A.-Z. Duvander, \& A. Koslowski (Eds.), Parental leave and beyond (pp. 125-145). Bristol: Policy Press.

Ejrnæs, A. (2011). The impact of family policy and career interruptions on women's perceptions of negative occupational consequences of full-time home care. European Societies, 13(2), 239-256.

Esping-Andersen, G. (1990). The three worlds of welfare capitalism. Oxford: Polity Press.

Esser, I. (2005). Why work? Comparative studies on welfare regimes and individuals' work orientations. Valdemarsvik: Akademitryck.

European Values Study. (2015). European values study longitudinal data file 1981-2008 (EVS 1981-2008, GESIS data archive, Cologne; ZA5174 data file version 1.0.0) [Data set]. https://doi.org/10.4232/1.5174

European Values Study. (2020). European values study 2017: Integrated dataset (EVS 2017, GESIS data archive, Cologne; ZA7500 data file version 3.0.0) [Data set]. https://doi.org/10.4232/1.13511

Eydal, G. B., Gíslason, I. V., Rostgaard, T., Brandth, B., Duvander, A.-Z., \& Lammi-Taskula, J. (2015). Trends in parental leave in the Nordic countries: Has the forward march of gender equality halted? Community, Work \& Family, 18(2), 167-181.

Eydal, G., \& Rostgaard, T. (2018). Fatherhood in five Nordic countries: Policies and practices. In R. Musumeci \& A. Santero (Eds.), Contemporary fathers balancing childcare and work: Cultures, practices and policies in a cross-country perspective (pp. 257-280). Bingley: Emerald.

Eydal, G. B., Rostgaard, T., \& Hiilamo, H. (2018). Family policies in the Nordic countries: Aiming at equality. In G. B. Eydal \& T. Rostgaard (Ed.), Handbook in child and family policy (pp. 195-208). London: Edward Elgar.

Geisler, E., \& Kreyenfeld, M. (2011). Against all odds: Fathers' use of parental leave in Germany. Journal of European Social Policy, 21(1), 88-99.

Geisler, E., \& Kreyenfeld, M. (2019). Policy reform and fathers' use of parental leave in Germany: The role of education and workplace characteristics. Journal of European Social Policy, 29(2), 273-291.

Grunow, D., Begall, K., \& Buchler, S. (2018). Gender ideologies in Europe: A multidimensional framework. Journal of Marriage and Family, 80(1), 42-60.

Haas, L., \& Rostgaard, T. (2011). Fathers' rights to paid parental leave in the Nordic countries: Consequences for the gendered division of leave. Community, Work \& Family, 14(2), 177-195.

Hakim, C. (2000). Work-lifestyle choices in the 21st century. Oxford: Oxford University Press.

Hakim, C. (2004). Lifestyle preferences versus patriarchal values: Causal and non-causal attitudes. In J. Zollinger Giele \& E. Holst (Eds.), Changing life patterns in Western industrial societies (pp. 69-94). London: Elsevier.

Hernes, H. (1987). Women and the welfare state: The transition from private to public dependence. In A. S. Sassoon (Ed.), Women and the state (pp. 72-92). London: Hutchinson.

Kangas, O., \& Rostgaard, T. (2007). Preferences or institutions? Work-family life opportunities in seven European countries. Journal of European Social Policy, 17(3), 240-256.

Kingdon, J. W. (1984). Agendas, alternatives and public policies. Boston: Little, Brown and Company.

Korpi, W. (2000). Faces of inequality: Gender, class, and patterns of inequalities in different types of welfare states. Social Politics: International Studies in Gender, State \& Society, 7(2), 127-191.

Lewis, J. (1992). Gender and the development of welfare regimes. Journal of European Social Policy, 2(3), 159-173.

Lewis, J. (Ed.). (1993). Women and social policies in Europe: Work, family and the state. Aldershot: Edward Elgar.

Lewis, S., \& Haas, L. (2005). Work-life integration and social policy: A social justice theory and gender equity approach to work and family. In E. E. Kossek \& S. Lambert (Eds.), Work and life integration: Organizational, cultural and psychological perspectives in a global world (pp. 349-374). Mahwah, NJ: Lawrence Erlbaum Associates.

Moss, P., \& Duvander, A.-Z. (Eds.). (2019). Parental leave and beyond: Recent international developments, current issues and future directions. Bristol: Policy Press.

NOSOSCO. (n.d). SOCI04: Recipients of daily cash benefits at pregnancy, childbirth and adoption by time, content and reporting country. Nordic Council of Ministers. Retrieved from https://www.nordicstatistics. org/social-integration-and-income 
OECD. (n.d.). The family data base. OECD. Retrieved from http://www.oecd.org/els/family/database.htm

Papadakis, E., \& Bean, C. (1993). Popular support for the welfare state: A comparison between institutional regimes. Journal of Public Policy, 13(2), 227-254.

Rostgaard, T. (2014). Nordic care and care work in the public service model of Denmark: Ideational factors of change. In M. Leon (Ed.), Care regimes in transitional European societies (pp. 182-207). London: Palgrave Macmillan.

Rostgaard, T. (2018a). Childcare as a global policy agenda. In G. B. Eydal \& T. Rostgaard (Eds.), Handbook in child and family policy (pp. 96-110). London: Edward Elgar.

Rostgaard, T. (2018b). The policy road to better and more affordable care for all children? EU thematic discussion paper. Peer review on "Furthering quality and flexibility of early childhood education and care." Brussels: European Commission.

Rostgaard, T., \& Lausten, M. (2014). The coming and going of the father's quota in Denmark: Consequences for fathers' parental leave take-up. In G. Eydal \& T. Rostgaard (Eds.), Caring fathers in the Nordic welfare states: Policies and practices of contemporary fatherhoods (pp. 277-302). London: Policy Press.

Sjöberg, O. (2004). The role of family policy institutions in explaining gender-role attitudes: A comparative multilevel analysis of thirteen industrialized countries. Journal of European Social Policy, 14(2), 107-123.
Statistics Denmark. (n.d.-a). LBESK03: Lønmodtagere (sæsonkorrigeret) efter branche (DBO7 10-og 19-grp) [LBESK03: Employees (seasonally adjusted) by industry (DB07 10- and 19-grp); Data set]. Retrieved from https://www.statbank.dk/ statbank5a/SelectVarVal/Define.asp?Maintable= LBESK03\&PLanguage $=0$

Statistics Denmark. (n.d.-b). BARSEL05: Samboende forældres barselsorlov $i$ barnets første leveår opgjort i hele dage efter enhed, dagpengeret, orlov, uddannelseskombination og område [BARSEL05: Cohabiting parents' leave in the child's first year of life calculated in whole days by unit, benefit entitlement, leave, educational combination and area; Data set]. Retrieved from https://www.statbank.dk/ statbank5a/SelectVarVal/Define.asp?MainTable= BARSEL05\&PLanguage $=0 \& P X S I d=0 \&$ wsid $=$ cftree

Statistics Denmark. (n.d.-c). BARSEL04: Forældres barselsorlov $i$ barnets første leveår opgjort $i$ hele dage efter enhed, dagpengeret, orlov, uddannelseskombination og område [BARSEL04: Parents' leave in the child's first year of life calculated in full days by unit, benefit entitlement, leave, educational combination and area; Data set]. Retrieved from https://www. statbank.dk/statbank5a/SelectVarVal/Define.asp? Maintable $=$ BARSELO4\&PLanguage $=0$

Thelen, K. (2004). How institutions evolve: The political economy of skills in Germany, Britain, the United States, and Japan. New York, NY: Cambridge University Press.

\section{About the Authors}

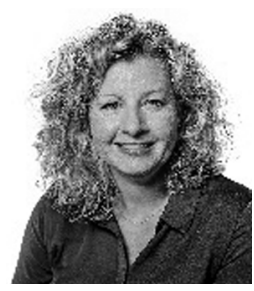

Tine Rostgaard is Professor (MSO) at the Social Science Department of Social Sciences and Business, Roskilde University. She conducts research into social care for children and older people, including parental leave. She is the co-chair at the international researcher network Transforming Care Network and is currently working on a handbook on social care policies to be published by Edward Elgar Publishing.

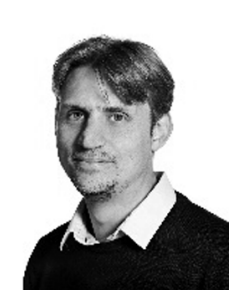

Anders Ejrnæs is Professor (MSO) at the Social Science Department of Social Sciences and Business, Roskilde University. His most recent publications have focused on comparative analysis of political engagement, wellbeing and happiness and work life balance across European states. He is currently working on explaining changing values across European states. 